\title{
The effect of air movement, air temperature and infrared radiation on the energy requirements of sheep
}

\author{
By J. P. JOYCE AND K. L. BLAXTER \\ Hannah Dairy Research Institute, Ayr
}

\section{(Received 25 February 1963-Accepted 6 September 1963)}

In Britain sheep are normally kept out-of-doors in winter and on hill farms they may be exposed to very severe weather conditions. On some hill farms pregnant ewes weighing $100 \mathrm{lb}$ at the beginning of winter may well weigh $80 \mathrm{lb}$ just before they lamb if the intervening winter weather has been severe. Deaths of ewes and more particularly of newborn lambs can be very many in bad winters (Robinson, 1953). Part of the weight loss may be attributed to lack of food and many of the deaths to starvation, but an increase in the energy requirement of sheep due to the stresses imposed by cold, wind, rain and snow must also be considered. The stresses of cold and lack of food are usually conjoint, for ice and snow make it impossible for the hill sheep to gather food. Similar climatic stresses also occur in New Zealand. Many deaths occur when cold weather with wind follows a second shearing of sheep in winter time.

Little is known of the increase in the energy expenditure of sheep that occurs in such adverse circumstances. Calorimetric experiments with adult sheep (Graham, Wainman, Blaxter \& Armstrong, 1959; Blaxter, Graham \& Wainman, 1959; Blaxter Graham, Wainman \& Armstrong, 1959; Armstrong, Blaxter, Clapperton, Graham \& Wainman, 1960) have shown that at maintenance levels of feeding the critical temperature of sheep, defined as the air temperature below which heat production increases, falls from about $30^{\circ}$ for sheep with $2 \mathrm{~mm}$ fleece to $20^{\circ}$ for those with $18 \mathrm{~mm}$ fleece, to $10^{\circ}$ for those with $35 \mathrm{~mm}$ fleece and to about $-3^{\circ}$ for those with $100 \mathrm{~mm}$ fleece. The increase in energy requirement in environments with temperatures below these critical temperatures can be predicted. These critical temperatures, however, refer to the environmental conditions in the instrument used to measure them, namely a low air velocity and a higher incoming i.r. radiation than is common out-ofdoors. Golding (1961) has recently pointed out that in west Scotland the annual mean wind speed is $12.5-17.5$ miles $/ \mathrm{h}$ and that on hill sites on Harris and on Islay the mean annual wind speed is 27 miles/h. It is certain that the estimates of critical temperatures made in calorimeters in which air velocity is about $0.4-0.6 \mathrm{miles} / \mathrm{h}$ are gross underestimates when winds of this magnitude are encountered.

The experiments reported below were undertaken to examine the effects of wind velocity on the energy expenditure of sheep under controlled conditions and to find how long it takes sheep to reach constant heat production after changes in air temperature, air velocity and incoming long-wave radiation intensity. All these experiments were regarded as essential preliminaries to studies planned to take place in 
natural environments where air velocity, wind direction, long- and short-wave incoming radiation and air temperature are subject to considerable variation from time to time.

\section{EXPERIMENTA L}

Animals. Four well-trained wether sheep were used as experimental animals. Sheep $C s$ was a Cheviot, sheep $Y l$ a Down cross and sheep $Z k$ and $C t$ were both Scottish Blackfaces. Each sheep had been tracheostomized several weeks before the experiment began and the trachea intubated by a method previously described (Blaxter \& Joyce, I963).

Food. Each sheep was given daily in two meals throughout the series of experiments a ration of $750 \mathrm{~g}$ artificially dried grass containing $16.5 \%$ crude protein. The amount was calculated to provide sufficient energy to maintain body-weight in a thermoneutral environment.

Respiration chamber experiments. The heat production and heat emission of each sheep were measured in a thermoneutral environment in a respiration chamber for periods of at least 4 days. With sheep $C s, Y l$ and $C t$, heat production and heat emission were also measured for similar periods when the temperature of the respiration chamber was reduced to well below the sheep's critical temperature. These latter experiments were made to establish the minimal loss of heat by vaporization of water from the skin and respiratory passages.

Experiments with Douglas bags. The method of collecting and measuring air expired by tracheostomized sheep has been described (Blaxter \& Joyce, 1963). Unless otherwise stated, all collections were continuous, the tap connecting the outlet from the valves on the trachea to one Douglas bag simply being turned to the next. Collections of expired air were usually of 20 min duration.

Equilibrium experiments. The times taken to attain equilibrium of body and skin temperatures and of oxygen consumption after changes in air velocity, i.r. radiation intensity and ambient air temperature were measured in experiments, the description of which follows.

Sheep $C s$ and $Y l$ were used to study the time taken to reach equilibrium when air velocity was changed. The sheep were fitted with a retaining harness of light weight, thermocouples were cemented to the skin and collection of expired air began at 9.00 $\mathrm{am}$. At least $\mathrm{I} h$ was allowed to establish an initial equilibrium when measurements of the initial values began. These continued for $\mathrm{I} h$. Then air velocity was increased by means of fans from that of the undisturbed air in the room to 6.2 or $8.9 \mathrm{miles} / \mathrm{h}$. The fans were switched off after $2 \mathrm{~h} 20 \mathrm{~min}$. Measurements continued for a further $2 \mathrm{~h}$ to trace the re-establishment of an equilibrium in 'still' air. Eight experiments of this type were made with sheep $C s$, four with the side of the sheep at right angles to the wind and four with the hind quarters at right angles to the wind. Two experiments were made with sheep $Y l$, one with the side and one with the hind quarters presented to the wind.

Sheep $C s$ and $Y l$ were used in four experiments to study the time taken to reach an equilibrium when ambient temperature was changed. Each sheep was first kept in a transportable pen at a temperature of $15^{\circ}$ in the anteroom of a climatic room. After 
45-60 min had been allowed to establish an equilibrium, initial measurements were made for $\mathrm{I} h$. The pen and sheep were then carried to the climatic room in which the temperature was $0^{\circ}$, the transfer taking 3-4 min. Measurements were made in the cold for $2 \mathrm{~h} 20 \mathrm{~min}$, when the sheep was returned to the warm anteroom and the measurements continued for a further $2 \mathrm{~h}$. Two experiments were made in which the temperature of the cold room was the same as that of the anteroom, to find whether the act of carrying the sheep and the transfer to new surroundings affected metabolism.

Sheep $C s$ and $Y l$ were also used in four experiments in which i.r. radiation intensity was increased by means of a series of eight $25^{\circ} \mathrm{W}$ i.r. lamps. After an initial adjustment period of $45 \mathrm{~min}$, measurements were made for $\mathrm{I} \mathrm{h,} 2 \mathrm{~h} 20 \mathrm{~min}$, and $2 \mathrm{~h}$ with no radiation, radiation and no radiation respectively.

Air velocity experiments. As discussed later, it was found that steady states of $\mathrm{O}_{2}$ consumption and of surface temperature were certainly reached $60 \mathrm{~min}$ after a change in climate. Experiments ( $\mathrm{r} 2 \mathrm{2}$ in all) were then made in which metabolism and skin and body temperatures were measured in environments in which the air velocity varied. Each experiment consisted of three or four consecutive periods of observation each lasting $20 \mathrm{~min}$. These followed an initial period of adjustment to the environment of at least 30 and usually $45 \mathrm{~min}$. Sheep $C t$ and $Z k$ were each used in eight experiments when they had a full fleece. Sheep $Y l$ was used in thirty-eight experiments during the course of which its fleece was allowed to grow from 6 to $20 \mathrm{~mm}$. Sheep $C s$ was used in fifty-eight experiments during which its fleece was allowed to grow from 19 to $50 \mathrm{~mm}$. These fleece depths were the means of measurements made with an engineer's depth gauge on about thirty sites on the wool-covered area. Wind velocity varied from a minimum of 0.2 to a maximum of $9.6 \mathrm{miles} / \mathrm{h}$. Air temperature varied from $-5^{\circ}$ to $10^{\circ}$, being kept constant to within $\pm 0.2^{\circ}$ in any one experiment.

foint effects of radiation and wind. Sheep $C s$ and $Y l$ were each used in two series of experiments in which the following sequence of experimental treatment was imposed at an ambient temperature of $0^{\circ}$ : no wind and no radiation, no wind with radiation, radiation with wind, and no radiation with wind. The wind speed was $9.6 \mathrm{miles} / \mathrm{h}$ and after an adjustment period of $30 \mathrm{~min}$ to each treatment measurements were made continuously for I h 20 min.

Respiration chambers and calorimetric methods. The respiration chamber of Wainman $\&$ Blaxter (1958) was used. Methods for determining heat production and minimal water vapour loss were those described by Armstrong et al. (1960).

Air velocity and its measurement. Two 12 in. diameter fans activated by variablespeed motors placed $5.5 \mathrm{ft}$ from the sheep were used to produce changes in air velocity. They were mounted with their centres $19 \mathrm{in}$. apart and $2 \mathrm{I}$ in. from the ground, and produced a steady flow of air without turbulence around the sheep. High velocities of the air stream were measured with precision cup anemometers (Messrs Casella, London) mounted in the position normally occupied by the sheep. Silvered katathermometers were used to measure low air velocities and Bedford \& Warner's (r933) formula was employed to convert cooling powers to air velocities.

Ambient environments. In some experiments, measurements were made in an airconditioned building, but most experiments, including all those at environmental 
temperatures below $5^{\circ}$, were made in a climatic room (Findlay, McLean \& Bennet, 1959).

Body and surface temperatures. Thermocouples were made of 40 s.w.g. copper and constantan wire and were cemented to the skin surface with floor sealing compound (Dunlop Rubber Co. Ltd). The rectal thermocouple was encased in a sealed Polythene ('Portex', Portland Plastics Ltd) tube. Measurements were made of the temperature of the skin of both the trunk and the legs on eight sites. Where mean skin temperature is referred to, the value was obtained by multiplying the mean value for the six sites on the trunk by 0.9 and the mean value for the two sites on the legs by $0 . \mathrm{I}$. The two coefficients are the proportions of hair-covered and fleece-covered areas respectively (Blaxter, Graham \& Wainman, 1959). The output from the thermocouples was recorded with an eight-channel potentiometric recorder.

Gas analysis. The $\mathrm{O}_{2}$ content of expired air was measured with a paramagnetic oxygen analyser (Cambridge Instrument Co. Ltd). Carbon dioxide and methane were determined from their thermal conductivity (Cambridge Instrument Co. Ltd). The accuracy and calibration of the analysers were checked each day by measuring the $\mathrm{O}_{2}, \mathrm{CO}_{2}$ and $\mathrm{CH}_{4}$ content of two standard compressed mixtures of these gases (Infra Red Development Co. Ltd), dry outdoor air and $\mathrm{O}_{2}$-free $\mathrm{N}_{2}$. Periodic checks of the apparatus were made by analysing samples of expired air by the Haldane method.

Insulations. Insulations are defined as temperature gradients divided by heat flows per unit time per unit area. The units employed are ${ }^{\circ} \mathrm{C}, \mathrm{kcal} / 24 \mathrm{~h}$ and $\mathrm{m}^{2}$ and, since the final expression is cumbersome, unit insulation is defined:

$$
\text { unit insulation }=\frac{\text { temperature gradient }\left({ }^{\circ} \mathrm{C}\right)}{\text { heat flow (kcal) per } \mathrm{m}^{2} \text { surface per } 24 \mathrm{~h}} \times 10^{-3} \text {. }
$$

\section{RESULTS}

Accuracy of measurements of $\mathrm{O}_{2}$ consumption by tracheal intubation. Table I summarizes the results of 129 experiments in which animals were subjected to particular environments for sufficient time for them to become accustomed. In each of these experiments either three or four consecutive determinations of $\mathrm{O}_{2}$ consumption were made, making 452 determinations in all. The standard deviations given in the table represent the error attached to a single determination. They varied from 0.9 to 2.51 . $\mathrm{O}_{2} / \mathrm{h}$, the largest value being for the sheep that on average consumed most $\mathrm{O}_{2}$. Coefficients of variation were all of the order of $\pm 6 \%$. The error attached to the mean of four consecutive determinations can be taken to be $\pm 3 \%$ of the amount determined and the same error can be taken to apply to estimates of heat production made from the equation given on p. 9 .

Calculation of total and sensible losses of heat. In planning experiments in which the effects of climatic variables were measured, it was essential to ensure that the environmental conditions would elicit a metabolic response by the sheep. The air temperature below which such metabolic responses occur is called the critical temperature and represents the lower limit of the zone of thermoneutrality. Obviously in environments of different i.r. radiation and of different air movement, the critical 
temperature defined as an air temperature will not be the same. If critical temperature is defined as an air temperature then other components of climate must be stated.

Table I. Errors attached to estimates of the oxygen consumption by four tracheostomized sheep obtained by the Douglas bag method

\begin{tabular}{|c|c|c|c|c|c|}
\hline Sheep & $\begin{array}{l}\text { No. of } \\
\text { expts }\end{array}$ & 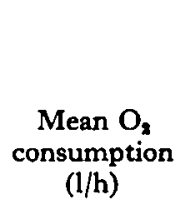 & $\begin{array}{c}\text { df } \\
\text { within } \\
\text { expts }\end{array}$ & $\begin{array}{l}\text { Estimated } \\
\text { standard } \\
\text { deviation } \\
\text { of } \mathrm{O}_{2} \\
\text { consumption } \\
\text { (l./h) }\end{array}$ & $\begin{array}{c}\text { Coefficient } \\
\text { of } \\
\text { variation } \\
(\%)\end{array}$ \\
\hline $\begin{array}{l}Y l \\
C t \\
Z k \\
C s\end{array}$ & $\begin{array}{r}44 \\
7 \\
9 \\
69\end{array}$ & $\begin{array}{l}40.5 \\
18.9 \\
16.2 \\
20.6\end{array}$ & $\begin{array}{r}112 \\
14 \\
19 \\
178\end{array}$ & $\begin{array}{l} \pm 2.49 \\
\pm 0.90 \\
\pm 1.24 \\
\pm 1.00\end{array}$ & $\begin{array}{l} \pm 6.17 \\
\pm 4.77 \\
\pm 7.70 \\
\pm 4.86\end{array}$ \\
\hline
\end{tabular}

It has been shown previously that, when the environmental temperature is below the critical temperature, the increase in heat production which consequently occurs is due to the combustion of body fat. The loss of heat by vaporization of water from the skin and respiratory passages under these conditions is remarkably constant (Blaxter, Graham \& Wainman, 1959). It is possible to assess whether any of the experiments made with Douglas bags was conducted in an environment effectively colder than the lower limit of the thermoneutral zone by comparing the measured $\mathrm{O}_{2}$ consumption with that determined in a thermoneutral environment in the respiration chamber. If measured $\mathrm{O}_{2}$ consumption was the greater, the animal was making a metabolic adjustment to cold. The calculation of heat production was then made from the measured $\mathrm{O}_{2}$ consumption. From simultaneous determinations of $\mathrm{O}_{2}$ consumption and $\mathrm{CO}_{2}$ and $\mathrm{CH}_{4}$ production and urinary $\mathrm{N}$ excretion made at hourly intervals during the day in the respiration chamber operated at environmental temperatures well above the critical temperature, heat production in a thermoneutral environment was calculated. If exactly the same ration was given and the animal was kept during the same period of the day in an environment that elicited a metabolic response to cold, heat production in this environment could be regarded as consisting of this 'normal' heat production plus an additional amount of heat arising from the additional body fat combusted. For every 1 . of $\mathrm{O}_{2}$ consumed when body fat is combusted $4.68 \mathrm{kcal}$ are produced. Heat production in an experiment can therefore be calculated from the expression:

$$
\begin{array}{r}
H_{P}=\left(\begin{array}{l}
\text { Total heat produced } / \mathrm{h} \\
\text { in an experiment }
\end{array}\right)=\left(\begin{array}{l}
\text { Heat produced } / \mathrm{h} \text { in a thermoneutral } \\
\text { environment }(A)
\end{array}\right) \\
+4.68\left\{\left(\begin{array}{l}
\mathrm{O}_{2} \text { consumed }(\mathrm{l} . / \mathrm{h}) \\
\text { in the experiment }
\end{array}\right)-\left(\begin{array}{l}
\mathrm{O}_{2} \text { consumed }(1 . / \mathrm{h}) \text { in a thermoneutral } \\
\text { environment }(B)
\end{array}\right)\right\}
\end{array}
$$

Clearly, if the experimental environment evoked no metabolic response, the parenthetical term was zero and heat production was then the same as that measured in the chamber under thermoneutral conditions. 
The sensible loss of heat by an animal $\left(H_{N}\right)$ is the total heat emitted less that lost by vaporization of water $\left(H_{E}\right)$ and that expended in warming ingested food and water from temperatures below body temperature to body temperature $\left(H_{W}\right)$. If body temperature is constant in an experimental period, that is no storage of heat in the body occurs, then heat production is equal to heat loss. Since in these experiments food and water were withheld during the period of observation, $H_{W}=0$ and $H_{N}=H_{P}-H_{E}$. If the animal is at an environmental temperature below its critical temperature $H_{E}$ is low and constant, and so from the estimate of $H_{P}$ given above $H_{N}$ can be obtained. Obviously this relationship cannot be used if the animal is in an environment above its critical temperature, that is if the parenthetical term in equation $\mathrm{I}$ is zero. $H_{Z Z}$ was determined in the respiration chamber for animals $C s, C t$ and $Y l$ when the experiments shown in Table 3 were made.

Table 2. Constants in the equations used to estimate heat production and the sensible heat loss from oxygen consumption

$\begin{array}{cccc}\begin{array}{c}\text { Heat production } \\ \text { in a thermo- } \\ \text { neutral } \\ \text { environment } \\ \text { (constant } A \text { in } \\ \text { equation } I^{*} \text { ) } \\ (\mathrm{kcal} / \mathrm{h})\end{array} & \begin{array}{c}\mathrm{O}_{2} \text { consumption } \\ \text { in a } \\ \text { thermoncutral } \\ \text { environment } \\ \text { (constant } B \\ \text { in equation } 1 *)\end{array} & \begin{array}{c}\text { Minimal loss of } \\ \text { heat by } \\ \text { vaporizing watert } \\ \text { (l/h) }\end{array} & \begin{array}{c}\text { (kcal/h) } \\ \text { Sheep }\end{array} \\ C s & 75.0 & 15.21 & 14.98 \pm 0.19 \\ C t & 75.8 & 15.32 & 15.78 \pm 0.19 \\ Y l & 80.2 & 16.16 & 15.60 \pm 0.30 \\ Z k & 72.2 & 14.28 & -\end{array}$

- See p. 9 .

+ Mean value with its standard error. The values derive from the last column of 'Table $\mathfrak{\jmath}$.

Table 2 summarizes the constants used to calculate heat production and the sensible loss of heat for each sheep. These were calculated from the respiration chamber experiments described below.

Metabolic experiments in the respiration apparatus. The results of ten experiments made in the respiration chamber are summarized in Table 3. At environmental temperatures of $18^{\circ}$ sheep $Z k$ and $C s$ stored energy in the body and sheep $C t$ and $Y l$ lost energy. The ration given was fairly close to a maintenance ration for all sheep. Their heat production at $18^{\circ}$ varied from a minimum of $180 \mathrm{rcal} / 24 \mathrm{~h}$ for sheep $C s$ to a maximum of $1892 \mathrm{kcal} / 24 \mathrm{~h}$ for sheep $\mathrm{Yl}$. Sheep $C t$ excreted about $100 \mathrm{kcal} / 24 \mathrm{~h}$ more energy in faeces than the other sheep. The reason for this is not known and is contrary to our experience of the behaviour of sheep given the same amount of food each day.

When the sheep were shorn and the environmental temperature was reduced to $5^{-} 8^{\circ}$, heat production increased without any significant change occurring in the loss of energy in faeces, in urine or as methane. Considerable losses of energy from the body then occurred.

The final column of Table 3 shows the determined losses of heat as water vapour at air temperatures of $5-8^{\circ}$. These were $360-380 \mathrm{kcal} / 24 \mathrm{~h}$. These values are in good agreement with previous estimates for sheep (Blaxter, Graham \& Wainman, 1959). 
Attainment of an equilibrium of temperature and $\mathrm{O}_{2}$ consumption after a change of wind speed. Fig. I shows the effects of changes in air velocity on the $\mathrm{O}_{2}$ consumption of sheep $C s$ and $Y l$. In each experiment the sheep was at an environmental temperature below its critical temperature when the air was still. In each of the graphs, therefore, where a metabolic response occurred unit scale length of $\mathrm{O}_{2}$ consumption $/ \mathrm{h}$ is equal to $4.68 \mathrm{kcal}$ heat production and the increases in heat production can be inferred from the $\mathrm{O}_{2}$ scale.

Table 3. Values for energy metabolism obtained in ten experiments with four sheep given constant rations in different environments in the respiration chamber

\begin{tabular}{|c|c|c|c|c|c|c|c|c|c|c|}
\hline \multirow[b]{2}{*}{ Sheep } & \multirow{2}{*}{\multicolumn{2}{|c|}{$\begin{array}{c}\text { Temper- } \\
\text { ature } \\
\text { e of } \\
\text { h chamber } \\
\text { comber } \\
\left({ }^{\circ} \mathrm{C}\right)\end{array}$}} & \multirow[b]{2}{*}{$\begin{array}{l}\text { No. of } \\
4 \text {-day } \\
\text { trials }\end{array}$} & \multicolumn{6}{|c|}{ Energy metabolism $(\mathrm{kcal} / 24 \mathrm{~h})$} & \multirow{2}{*}{$\begin{array}{c}\text { heat } \\
\text { as } \\
\text { water } \\
\text { vapour } \\
\text { (kcal/ } \\
24 \mathrm{~h} \text { ) }\end{array}$} \\
\hline & & & & Intake & $\begin{array}{c}\text { Faecal } \\
\text { loss }\end{array}$ & $\begin{array}{l}\text { Loss } \\
\text { as } \\
\text { methane }\end{array}$ & $\begin{array}{l}\text { Urinary } \\
\text { loss }\end{array}$ & $\begin{array}{c}\text { Loss } \\
\text { as } \\
\text { heat }\end{array}$ & Retained & \\
\hline Cs & $\begin{array}{r}69 \\
4\end{array}$ & $\begin{array}{l}18 \\
6.7\end{array}$ & $\begin{array}{l}\text { I } \\
\text { I }\end{array}$ & $\begin{array}{l}2891 \\
2891\end{array}$ & $\begin{array}{l}677 \\
705\end{array}$ & $\begin{array}{l}214 \\
2222\end{array}$ & $\begin{array}{l}132 \\
201\end{array}$ & $\begin{array}{l}1801 \\
3504\end{array}$ & $\begin{array}{l}+115 \\
-173^{8}\end{array}$ & 359 \\
\hline$C t$ & $\begin{array}{c}90-92 \\
6\end{array}$ & $\begin{array}{l}18 \\
7.6\end{array}$ & $\begin{array}{l}3 \\
1\end{array}$ & $\begin{array}{l}289 I \\
289 r\end{array}$ & $\begin{array}{l}754 \\
758\end{array}$ & $\begin{array}{l}255 \\
283\end{array}$ & $\begin{array}{l}206 \\
194\end{array}$ & $\begin{array}{l}1831 \\
3630\end{array}$ & $\begin{array}{l}-140 \\
-1924\end{array}$ & 379 \\
\hline$Y l$ & $\begin{array}{l}60 \\
24\end{array}$ & $\begin{array}{l}18 \\
5 \cdot 4\end{array}$ & 2 & $\begin{array}{l}2891 \\
2891\end{array}$ & $\begin{array}{l}649 \\
684\end{array}$ & $\begin{array}{l}244 \\
218\end{array}$ & $\begin{array}{l}175 \\
159\end{array}$ & $\begin{array}{l}1892 \\
2924\end{array}$ & $\begin{array}{l}-\quad 68 \\
-1025\end{array}$ & 374 \\
\hline$Z k$ & 98 & 18 & I & 2891 & 648 & 232 & 169 & 1842 & +142 & - \\
\hline
\end{tabular}

With sheep $C s$ in both sets of experiments, switching on the fans led to a large rise in $\mathrm{O}_{2}$ consumption during the first $5 \mathrm{~min}$, which fell in the following $15 \mathrm{~min}$, and then either became virtually constant or fell slightly. The fall in $\mathrm{O}_{2}$ consumption in the experiments with a wind of $8.9 \mathrm{miles} / \mathrm{h}$ after the $15^{\text {th }}$ min was largely due to a slight increase in air temperature from $\mathrm{II} \cdot 4$ to $12 \cdot 2^{\circ}$ when the hind quarters were presented to the wind and from 14.3 to $14.8^{\circ}$ when the side was exposed. When the fans were switched off, $\mathrm{O}_{2}$ consumption immediately fell to values below those observed initially, but subsequently rose to steady values $20 \mathrm{~min}$ after the wind had been stopped. With sheep $\mathrm{Yl}$, a sheep with a thicker fleece, the early peak in $\mathrm{O}_{2}$ consumption did not occur, but the short depression of $\mathrm{O}_{2}$ consumption after the wind was stopped was again noted. With sheep $Y l, \mathrm{O}_{2}$ consumption was within $\mathrm{I} 1$./h of an equilibrium after 60 min of exposure to a change in air velocity. With sheep $C s, \mathrm{O}_{2}$ consumption was within $\mathrm{I} 1 \mathrm{~h} / \mathrm{h}$ of an equilibrium $20-40 \mathrm{~min}$ after a change in air velocity.

The early peak of $\mathrm{O}_{2}$ consumption with sheep $C s$ may have been due to fear and apprehension. Tests were made in which fans were started with smooth discs replacing the blades, thus creating some noise and a visual effect. $\mathrm{O}_{2}$ consumption was again measured but no increase occurred. An aural and visual stimulus similar to that in the experiments thus did not induce an increase in $\mathrm{O}_{2}$ consumption. The tactile stimulus of the wind hitting the skin could have been responsible for the early rise in $\mathrm{O}_{2}$ consumption. The effect may have been greater in sheep $C s$ with a short fleece than in sheep $Y l$ with a longer one. 
Table 4 summarizes measurements of skin temperature made in the experiments with side exposure. The temperatures of the windward and of the leeward sides of the trunk are the mean values for three sites on each. The fall in the temperature of the skin of the trunk on both the windward and leeward sides was very rapid, and after the first $5 \mathrm{~min}$ the subsequent fall was slow. The increase in skin temperature on the

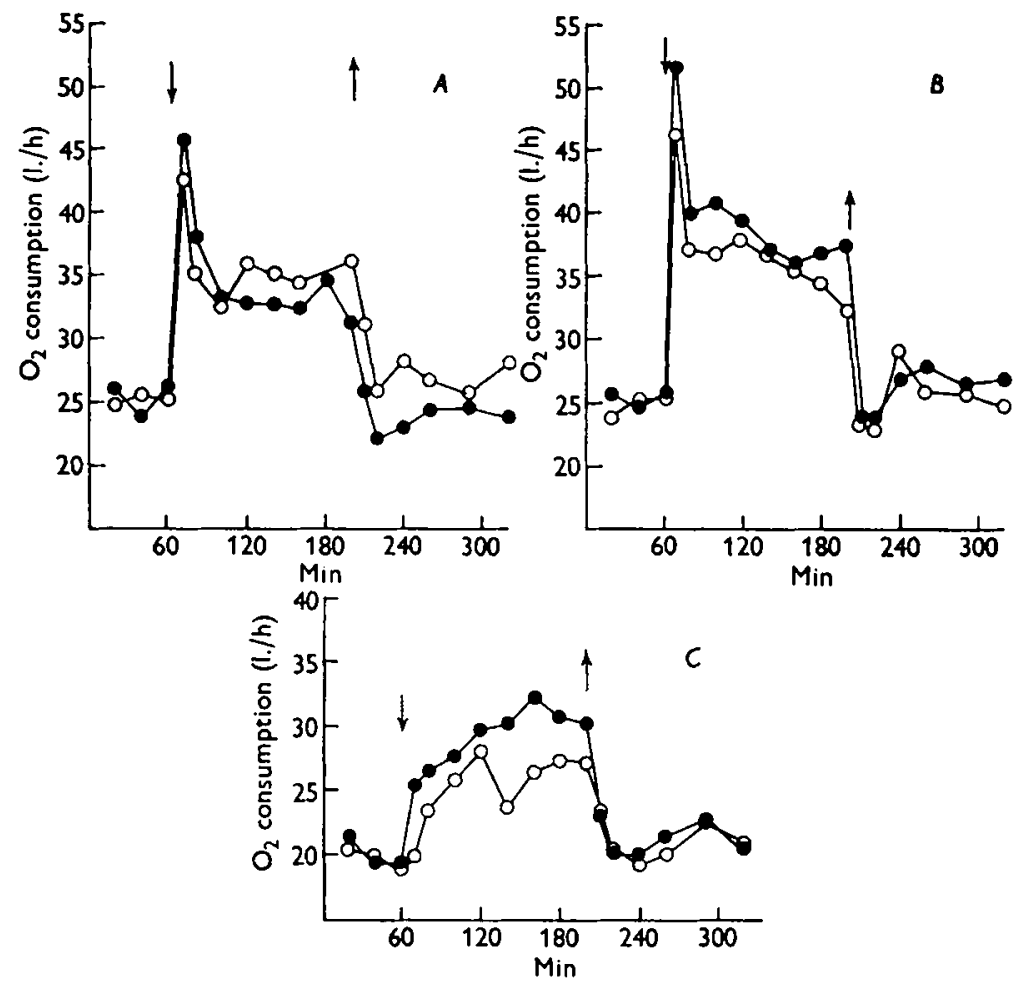

Fig. 1. Effect of changes in wind velocity on the oxygen consumption of sheep. $\downarrow$, wind velocity increased from $0.2 \mathrm{miles} / \mathrm{h} ; \uparrow$, wind velocity decreased to $0.2 \mathrm{miles} / \mathrm{h}$.

$(A)$ Sheep $C s:-\infty$, side exposed to a wind of $6.2 \mathrm{miles} / \mathrm{h}$ at an air temperature of $12^{\circ}$ when fleece length I $1 \mathrm{~mm} ; 0-0$, hind quarters exposed to a wind of $6.2 \mathrm{miles} / \mathrm{h}$ at an air temperature of $6.5^{\circ}$ when fleece length $12 \mathrm{~mm}$.

(B) Sheep Cs: - - - , side exposed to a wind of $8.9 \mathrm{miles} / \mathrm{h}$ at an air temperature of $15^{\circ}$ when fleece length $6 \mathrm{~mm} ; 0-0$, hind quarters exposed to a wind of $8.9 \mathrm{miles} / \mathrm{h}$ at an air temperature of $12^{\circ}$ when fleece length $6 \mathrm{~mm}$.

(C) Sheep $Y l:-\infty$, side exposed to a wind of $8.9 \mathrm{miles} / \mathrm{h}$ at an air temperature of $\mathrm{I}^{\circ}$ when fleece length $35 \mathrm{~mm} ; 0-0$, hind quarters exposed to a wind of $8.9 \mathrm{miles} / \mathrm{h}$ at an air temperature of $2^{\circ}$ when fleece length $35 \mathrm{~mm}$.

wind's being stopped was equally rapid. In all experiments the temperature of the skin on the windward side of the trunk fell more than on the leeward side; indeed with sheep $Y l$, with $35 \mathrm{~mm}$ fleece, no change in the surface temperature of the leeward side of the trunk took place although that of the windward side fell by $8^{\circ}$. The fall in the temperature of the fetlock on exposure to wind was the same on both sides of the animal when one side was presented; this could possibly be accounted for by a low air velocity close to the floor caused by a surface drag. The rate of fall of foot tem- 
perature was smaller than that of trunk temperature except with sheep $C s$ exposed to a wind of 8.9 miles $/ \mathrm{h}$. The rate of increase in the temperature of the skin of the foot on the wind's being stopped was also smaller than that noted for the trunk.

Table 4. Effect of wind on the mean skin temperature of the windward and leeward sides of the trunk and of the legs of two sheep with their side presented to the wind. Each observation is the mean for two exposures

\begin{tabular}{|c|c|c|c|c|c|c|c|c|c|c|c|}
\hline \multirow{2}{*}{$\begin{array}{l}\text { Site of } \\
\text { measure- } \\
\text { ment }\end{array}$} & \multirow[b]{2}{*}{ Sheep } & \multirow{2}{*}{$\begin{array}{c}\text { Fleece } \\
\text { length } \\
(\mathrm{mm})\end{array}$} & \multirow{2}{*}{$\begin{array}{l}\text { Wind A } \\
\text { speed } \\
\text { (miles/h) }\end{array}$} & \multirow{2}{*}{$\begin{array}{l}\text { Air temper- } \\
\text { ature } \\
\left({ }^{\circ} \mathrm{C}\right)\end{array}$} & \multicolumn{7}{|c|}{ Skin temperature $\left({ }^{\circ} \mathrm{C}\right)$ after exposure to wind for } \\
\hline & & & & & $\circ \mathrm{min}$ & $5 \mathrm{~min}$ & $10 \mathrm{~min}$ & $20 \mathrm{~min}$ & $40 \mathrm{~min}$ & $80 \mathrm{~min}$ & $140 \mathrm{~min}$ \\
\hline $\begin{array}{l}\text { Windward sites } \\
\text { on trunk }\end{array}$ & $\begin{array}{c}C s \\
C s \\
Y l\end{array}$ & $\begin{array}{r}\text { II } \\
6 \\
35\end{array}$ & $\begin{array}{l}6 \cdot 2 \\
8 \cdot 9 \\
8 \cdot 9\end{array}$ & $\begin{array}{r}12 \\
15 \\
1\end{array}$ & $\begin{array}{l}29 \cdot 0 \\
31 \cdot 1 \\
35 \cdot 0\end{array}$ & $\begin{array}{l}25 \cdot 5 \\
25 \cdot 0 \\
29 \cdot 4\end{array}$ & $\begin{array}{l}25 \cdot 4 \\
24 \cdot 9 \\
28 \cdot 4\end{array}$ & $\begin{array}{l}24 \cdot 6 \\
24 \cdot 4 \\
27 \cdot 6\end{array}$ & $\begin{array}{l}25 \cdot 3 \\
24 \cdot 0 \\
27 \cdot 3\end{array}$ & $\begin{array}{l}25 \cdot 1 \\
23 \cdot 4 \\
27 \cdot 1\end{array}$ & $\begin{array}{l}24 \cdot 9 \\
23 \cdot 7 \\
27 \cdot 6\end{array}$ \\
\hline $\begin{array}{l}\text { Leeward sites } \\
\text { on trunk }\end{array}$ & $\begin{array}{l}C s \\
C s \\
Y l\end{array}$ & $\begin{array}{r}11 \\
6 \\
35\end{array}$ & $\begin{array}{l}6 \cdot 2 \\
8 \cdot 9 \\
8 \cdot 9\end{array}$ & $\begin{array}{r}12 \\
15 \\
1\end{array}$ & $\begin{array}{l}29 \cdot 7 \\
31 \cdot 3 \\
35 \cdot 2\end{array}$ & $\begin{array}{l}26 \cdot 9 \\
27 \cdot 5 \\
35 \cdot 1\end{array}$ & $\begin{array}{l}26 \cdot 5 \\
27 \cdot 7 \\
35 \cdot 0\end{array}$ & $\begin{array}{l}26 \cdot 0 \\
28 \cdot 1 \\
34 \cdot 7\end{array}$ & $\begin{array}{l}26 \cdot 4 \\
27 \cdot 7 \\
35 \cdot 2\end{array}$ & $\begin{array}{l}26 \cdot 7 \\
27 \cdot 6 \\
35 \cdot 1\end{array}$ & $\begin{array}{l}26 \cdot 2 \\
27 \cdot 5 \\
35 \cdot 1\end{array}$ \\
\hline $\begin{array}{c}\text { Fetlock on } \\
\text { both sides }\end{array}$ & $\begin{array}{l}C s \\
C s \\
Y l\end{array}$ & $\begin{array}{r}11 \\
6 \\
35\end{array}$ & $\begin{array}{l}6 \cdot 2 \\
8 \cdot 9 \\
8 \cdot 9\end{array}$ & $\begin{array}{r}12 \\
15 \\
1\end{array}$ & $\begin{array}{r}17 \cdot 2 \\
16 \cdot 8 \\
7 \cdot 0\end{array}$ & $\begin{array}{r}16 \cdot 8 \\
16 \cdot 1 \\
1 \cdot 7\end{array}$ & $\begin{array}{r}16 \cdot 1 \\
16 \cdot 5 \\
I \cdot 5\end{array}$ & $\begin{array}{r}15 \cdot 6 \\
16 \cdot 2 \\
1 \cdot 4\end{array}$ & $\begin{array}{r}14 \cdot 6 \\
15 \cdot 8 \\
1 \cdot 1\end{array}$ & $\begin{array}{r}14 \cdot 5 \\
15 \cdot 8 \\
I \cdot I\end{array}$ & $\begin{array}{r}13 \cdot 8 \\
16 \cdot 2 \\
1 \cdot 1\end{array}$ \\
\hline
\end{tabular}

The temperatures of the skin surfaces of the sheep when their hind quarters were presented to the wind were very different from those noted when their sides were presented. Table 5 gives the mean values obtained after exposure for $\mathbf{2 h}$, that is after attainment of an equilibrium. It shows that when one side was presented to a wind a gradient of skin temperature from the windward to the leeward side developed. Hind-quarter presentation intensified the small natural gradient from the posterior to the anterior of the animal. In each experiment depicted in Fig. I, side exposure resulted in a greater $\mathrm{O}_{2}$ consumption than hind-quarter exposure. The air temperatures were not the same for the two presentations in any one of the three sets of experiments, and direct comparison of skin temperatures for side and hind-quarter presentation is not therefore possible.

Attainment of an equilibrium of temperature and $\mathrm{O}_{2}$ consumption after a change in air temperature. Fig. 2 shows the changes in $\mathrm{O}_{2}$ consumption of sheep $C s$ and of sheep $Y l$ when they were rapidly transferred from a room with an air temperature of $16^{\circ}$ to a room with an air temperature of $0^{\circ}$. Each graph is the mean of the results of two experiments. Sheep $C s$ had a fleece of $38 \mathrm{~mm}$ and sheep $Y l$ one of $3 \mathrm{~mm}$, and the mean response to cold was greater in the latter animal. In the first 10 min after the transfer to the cold room $\mathrm{O}_{2}$ consumption was markedly increased. This effect was clearly due to the disturbance caused by the act of transfer, because in the control experiments in which each sheep was transferred from the one room to the other, both rooms being at the same temperature, similar increases in $\mathrm{O}_{2}$ consumption took place. This observation supports the contention that the immediate high consumption of $\mathrm{O}_{2}$ on subjecting animal $C s$ to wind (see p. II) was due to disturbance. The response of $\mathrm{O}_{2}$ consumption to environmental temperature was clearly completed very quickly, certainly within 40 min of exposure, whatever the direction of the change in air temperature. Skin temperatures attained stable values very rapidly, except for the temperatures of the feet. The temperature of the skin of the fetlock of sheep $Y l$, for 
Table 5. Mean temperatures of skin of two sheep after exposure of the side or hind quarters for more than $2 h$ to wind

\begin{tabular}{|c|c|c|c|c|c|c|c|}
\hline \multirow[b]{3}{*}{ Sheep } & \multirow{3}{*}{$\begin{array}{c}\text { Fleece } \\
\text { length } \\
(\mathrm{mm})\end{array}$} & \multirow{3}{*}{$\begin{array}{c}\text { Wind } \\
\text { speed } \\
(\text { miles } / \mathrm{h})\end{array}$} & & \multicolumn{4}{|c|}{ Skin temperature $\left({ }^{\circ} \mathrm{C}\right)$} \\
\hline & & & & \multicolumn{2}{|c|}{$\begin{array}{c}\text { Left side of } \\
\text { sheep to wind }\end{array}$} & \multicolumn{2}{|c|}{$\begin{array}{l}\text { Hind quarters } \\
\text { of sheep to wind }\end{array}$} \\
\hline & & & Site & $\begin{array}{l}\text { Left } \\
\text { side }\end{array}$ & $\begin{array}{l}\text { Right } \\
\text { side }\end{array}$ & $\begin{array}{l}\text { Left } \\
\text { side }\end{array}$ & $\begin{array}{l}\text { Right } \\
\text { side }\end{array}$ \\
\hline \multirow[t]{2}{*}{$Y l$} & \multirow[t]{2}{*}{35} & \multirow[t]{2}{*}{$8 \cdot 9$} & Air & \multicolumn{2}{|c|}{$1 \cdot 0$} & \multicolumn{2}{|c|}{$1 \cdot 8$} \\
\hline & & & $\begin{array}{l}\text { Shoulder } \\
\text { Mid-side } \\
\text { Hip } \\
\text { Hind fetlock }\end{array}$ & $\begin{array}{l}3 I \cdot 3 \\
28 \cdot 5 \\
23 \cdot 0 \\
-\end{array}$ & $\begin{array}{r}35 \cdot 5 \\
35 \cdot 2 \\
34 \cdot 6 \\
1 \cdot 1\end{array}$ & $\begin{array}{l}33 \cdot 4 \\
32 \cdot 5 \\
29 \cdot 2 \\
-\end{array}$ & $\begin{array}{r}33 \cdot 0 \\
31 \cdot 2 \\
29 \cdot 6 \\
3 \cdot 7\end{array}$ \\
\hline \multirow[t]{2}{*}{$C s$} & \multirow[t]{2}{*}{ I I } & \multirow[t]{2}{*}{$6 \cdot 2$} & Air & \multicolumn{2}{|c|}{12.0} & \multicolumn{2}{|c|}{6.4} \\
\hline & & & $\begin{array}{l}\text { Shoulder } \\
\text { Mid-side } \\
\text { Hip } \\
\text { Hind fetlock }\end{array}$ & $\begin{array}{l}24 \cdot 1 \\
24 \cdot 9 \\
24 \cdot 8 \\
13.8\end{array}$ & $\begin{array}{l}29 \cdot 4 \\
26 \cdot 3 \\
26 \cdot 1 \\
14 \cdot 9\end{array}$ & $\begin{array}{r}25 \cdot 4 \\
24 \cdot 2 \\
23 \cdot 8 \\
8 \cdot 0\end{array}$ & $\begin{array}{r}25 \cdot 1 \\
25 \cdot 2 \\
23 \cdot 6 \\
7 \cdot 7\end{array}$ \\
\hline \multirow[t]{2}{*}{$C s$} & \multirow[t]{2}{*}{6} & \multirow[t]{2}{*}{$8 \cdot 9$} & Air & \multicolumn{2}{|c|}{$14 \cdot 8$} & \multicolumn{2}{|c|}{12.0} \\
\hline & & & $\begin{array}{l}\text { Shoulder } \\
\text { Mid-side } \\
\text { Hip } \\
\text { Hind fetlock }\end{array}$ & $\begin{array}{l}24 \cdot 4 \\
23 \cdot 2 \\
24 \cdot 2 \\
15 \cdot 4\end{array}$ & $\begin{array}{l}31 \cdot 6 \\
25 \cdot 8 \\
25 \cdot 8 \\
16.9\end{array}$ & $\begin{array}{l}25 \cdot 5 \\
21 \cdot 5 \\
20 \cdot 3 \\
15.6\end{array}$ & $\begin{array}{l}25.4 \\
21 \cdot 1 \\
19.8 \\
15.6\end{array}$ \\
\hline
\end{tabular}

example, fell on transfer to the cold from $17.8^{\circ}$ initially to $13.3^{\circ}$ at $5 \mathrm{~min}$, to $8.6^{\circ}$ at $60 \mathrm{~min}$ and to $6.3^{\circ}$ at $120 \mathrm{~min}$ after exposure. When the sheep was transferred back to the warmth, fetlock temperature rose to $9.6^{\circ}$ at $5 \mathrm{~min}, 12.0^{\circ}$ at $60 \mathrm{~min}$ and $15.0^{\circ}$ at $120 \mathrm{~min}$ after the change. The rate of change of the temperature of the skin of the extremities in response to a change in air temperature was thus slower than that of the trunk.

Attainment of an equilibrium of temperature and $\mathrm{O}_{2}$ consumption after a change in i.r. radiation intensity. Although experiments were made with two sheep to find the time taken to attain an equilibrium after a change in i.r. radiation intensity, only the mean results of two experiments with one sheep are presented in Fig. 3. The experiments with the other sheep were made when air temperature was above the critical temperature and no response of $\mathrm{O}_{2}$ consumption was therefore obtained. Fig. 3 shows that the response to i.r. heating was slow. It took about $60-80 \mathrm{~min}$ to reach a minimal heat production when heat was applied and $50 \mathrm{~min}$ to return to initial values when heating was stopped. The increase in trunk surface temperature on heating was maximal at $50 \mathrm{~min}$, and over $85 \%$ of the total increase was noted at the end of $2 \mathrm{~min}$. The initial decrease in trunk temperatures on cooling was slower than the initial increase on heating, only reaching $85 \%$ of the maximum at $20 \mathrm{~min}$. Again a slow rise in its temperature was noted after that time.

Conclusions on attainment of equilibrium. From the above experiments it was concluded that the responses of the $\mathrm{O}_{2}$ consumption of the sheep to sudden large changes in wind velocity were virtually complete $50 \mathrm{~min}$ after exposure; responses to sudden changes in air temperature were complete $30 \mathrm{~min}$ after exposure, and to changes in 


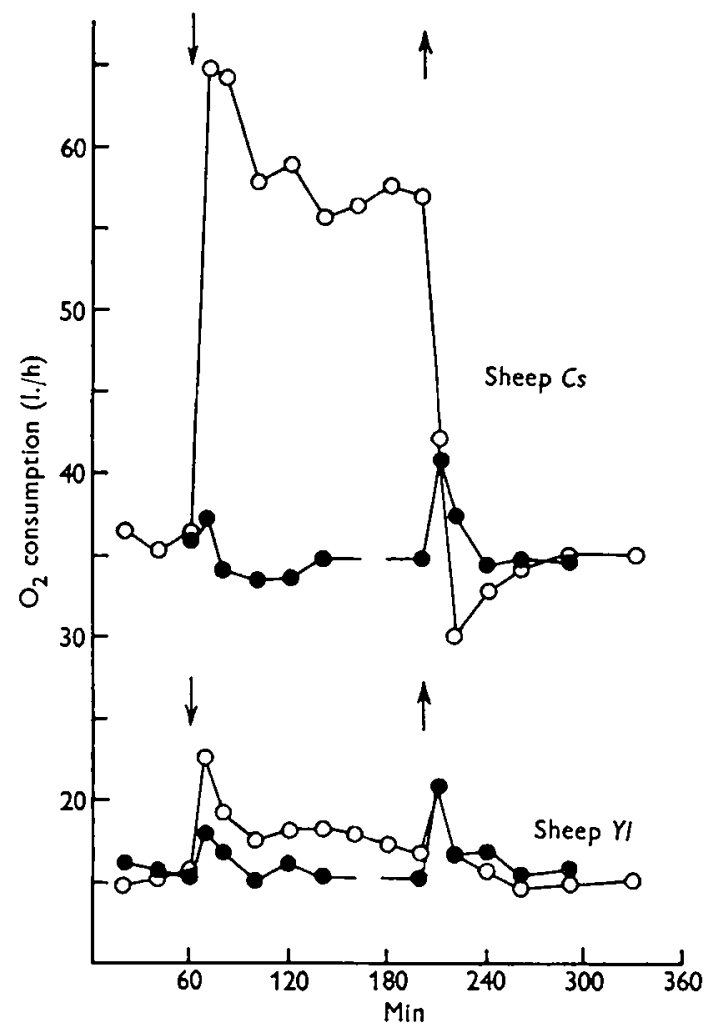

Fig. 2. Eiffect on oxygen consumption of transferring sheep $Y l$ and $C$ s from one room to another. - control experiments when temperature of two rooms was the same at $16.5^{\circ} ; 0-0$, experiments when the transfer at $(\downarrow)$ was from a room at $16.5^{\circ}$ to a room at $0^{\circ}$ and at $(\uparrow)$ was from $0^{\circ}$ to $16 \cdot 5^{\circ}$.

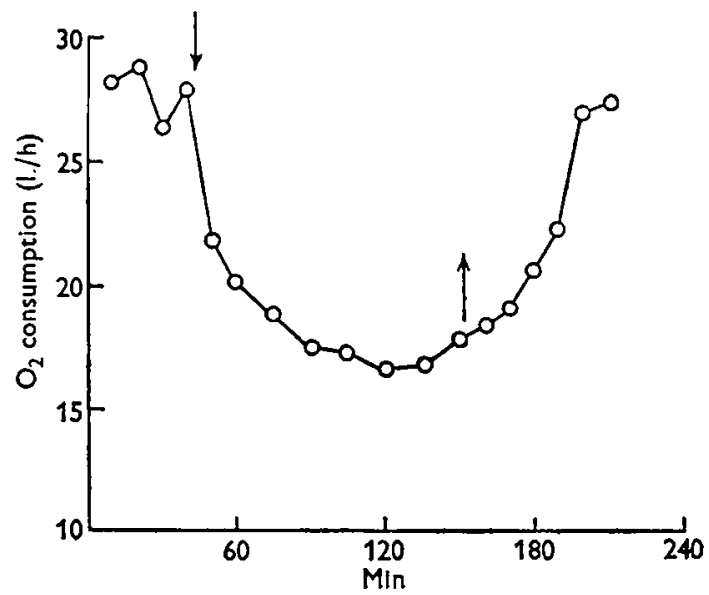

Fig. 3. Effect on the oxygen consumption of sheep $Y l$ of radiation from eight $240 \mathrm{~W}$ i.r. lamps. The air temperature was $0^{\circ}$ and fleece length was $17 \mathrm{~mm}$. The lamps were switched on at $(\downarrow)$ and off at $(\uparrow)$. 
Table 6. Mean heat production, body and surface temperatures and insulations of sheep exposed to different environments. Each of the results is the mean for duplicate measurements made on consecutive days

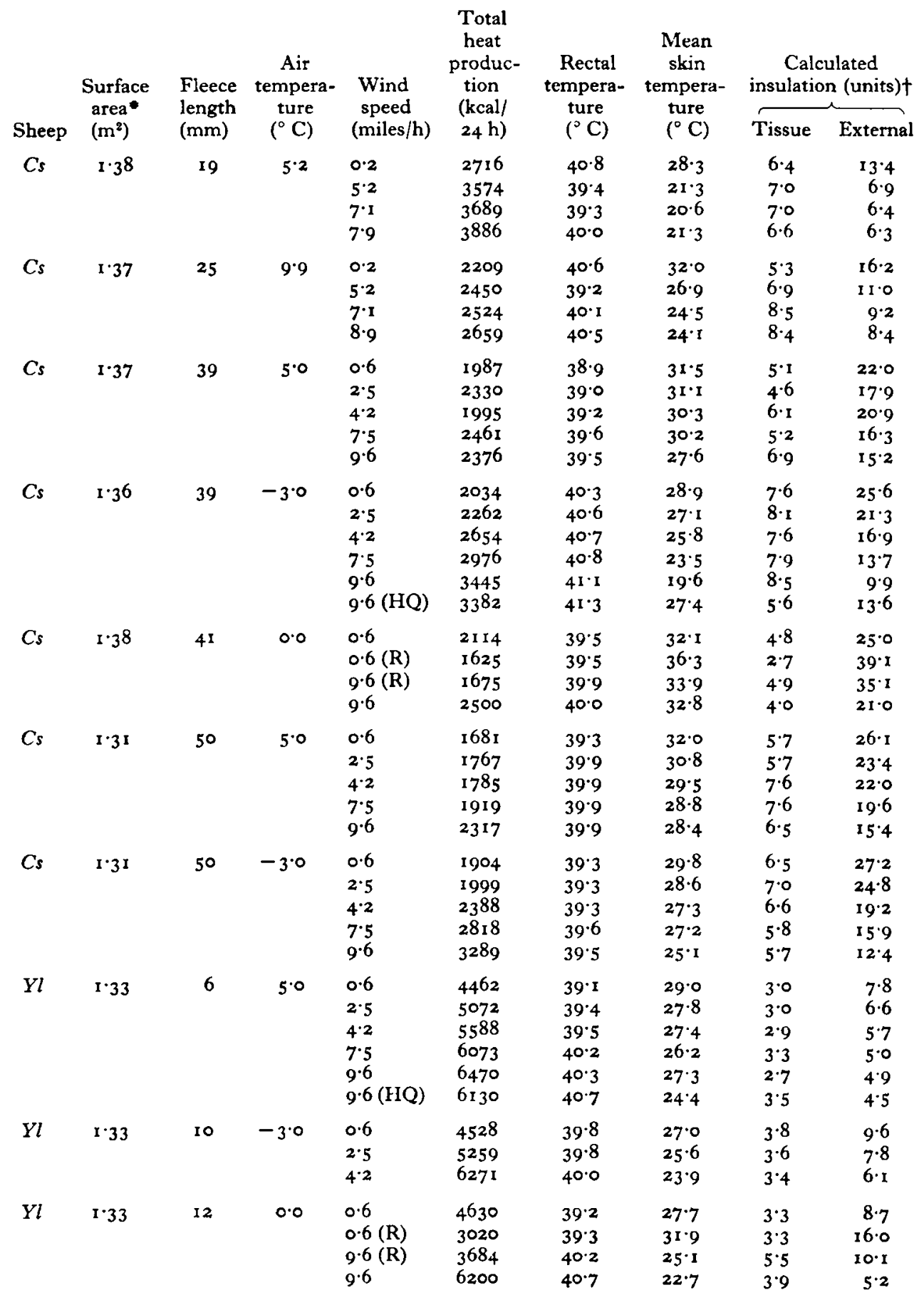


Table 6 (cont.)

\begin{tabular}{|c|c|c|c|c|c|c|c|c|c|}
\hline \multirow[b]{2}{*}{ Sheep } & \multirow{2}{*}{$\begin{array}{c}\text { Surface } \\
\text { area* } \\
\left(\mathrm{m}^{2}\right)\end{array}$} & \multirow{2}{*}{$\begin{array}{c}\text { Fleece } \\
\text { length } \\
(\mathrm{mm})\end{array}$} & \multirow{2}{*}{$\begin{array}{c}\text { Air } \\
\text { tempera- } \\
\text { ture } \\
\left({ }^{\circ} \mathrm{C}\right)\end{array}$} & \multirow{2}{*}{$\begin{array}{l}\text { Wind } \\
\text { speed } \\
(\text { miles/h) }\end{array}$} & \multirow{2}{*}{$\begin{array}{c}\text { Total } \\
\text { heat } \\
\text { produc- } \\
\text { tion } \\
(\mathrm{kcal} / \\
24 \mathrm{~h})\end{array}$} & \multirow{2}{*}{$\begin{array}{c}\text { Rectal } \\
\text { tempera- } \\
\text { ture } \\
\left({ }^{\circ} \mathrm{C}\right)\end{array}$} & \multirow{2}{*}{$\begin{array}{c}\text { Mean } \\
\text { skin } \\
\text { tempera- } \\
\text { ture } \\
\left({ }^{\circ} \mathrm{C}\right)\end{array}$} & \multicolumn{2}{|c|}{$\begin{array}{c}\text { Calculated } \\
\text { insulation (units) } \dagger\end{array}$} \\
\hline & & & & & & & & Tissue & External \\
\hline$Y l$ & $1 \cdot 28$ & 20 & -30 & $\begin{array}{l}0.6 \\
2.5 \\
4.2 \\
7.5 \\
9.6\end{array}$ & $\begin{array}{l}3875 \\
4318 \\
4699 \\
5024 \\
5328\end{array}$ & $\begin{array}{l}39 \cdot 3 \\
39 \cdot 5 \\
39 \cdot 6 \\
39 \cdot 9 \\
40 \cdot 4\end{array}$ & $\begin{array}{l}29 \cdot 0 \\
28 \cdot 2 \\
27 \cdot 6 \\
26 \cdot 2 \\
25 \cdot 0\end{array}$ & $\begin{array}{l}3 \cdot 4 \\
3 \cdot 3 \\
3 \cdot 3 \\
3 \cdot 5 \\
3 \cdot 7\end{array}$ & $\begin{array}{r}11 \cdot 7 \\
10 \cdot 1 \\
9 \cdot 0 \\
8 \cdot 0 \\
7 \cdot 2\end{array}$ \\
\hline Yl & $1 \cdot 28$ & 20 & 5.0 & $\begin{array}{l}0.6 \\
2.5 \\
4 \cdot 2 \\
7.5 \\
9 \cdot 6\end{array}$ & $\begin{array}{l}2562 \\
2769 \\
3199 \\
3455 \\
3937\end{array}$ & $\begin{array}{l}39 \cdot 3 \\
39 \cdot 6 \\
39 \cdot 7 \\
39 \cdot 8 \\
40 \cdot 0\end{array}$ & $\begin{array}{l}31 \cdot 1 \\
30 \cdot 3 \\
29 \cdot 4 \\
28 \cdot 5 \\
27 \cdot 6\end{array}$ & $\begin{array}{l}4 \cdot 1 \\
4 \cdot 3 \\
4 \cdot 1 \\
4 \cdot 2 \\
4 \cdot 0\end{array}$ & $\begin{array}{r}15 \cdot 2 \\
13 \cdot 4 \\
11 \cdot 0 \\
9 \cdot 7 \\
8 \cdot 1\end{array}$ \\
\hline$C t$ & $1 \cdot 42$ & 89 & $\begin{array}{l}5 \cdot 0 \\
6 \cdot 2 \\
6 \cdot 9 \\
5 \cdot 9\end{array}$ & $\begin{array}{l}0.2 \\
5 \cdot 2 \\
7 \cdot 1 \\
7 \cdot 9\end{array}$ & $\begin{array}{l}2054 \\
2054 \\
2255 \\
2366\end{array}$ & $\begin{array}{l}39 \cdot 4 \\
39 \cdot 5 \\
39 \cdot 6 \\
39 \cdot 2\end{array}$ & $\begin{array}{l}33 \cdot 4 \\
3 I \cdot 4 \\
30 \cdot 6 \\
3 I \cdot 1\end{array}$ & $\begin{array}{l}- \\
-\end{array}$ & $\begin{array}{l}- \\
- \\
-\end{array}$ \\
\hline$Z k$ & $x \cdot 49$ & 98 & $\begin{array}{r}9.1 \\
10.0 \\
9.6 \\
9.8\end{array}$ & $\begin{array}{l}0.2 \\
0.2 \\
8.9 \\
8.9\end{array}$ & $\begin{array}{l}1848 \\
1847 \\
1946 \\
2103\end{array}$ & $\begin{array}{l}39 \cdot 2 \\
40 \cdot 1 \\
40 \cdot 0 \\
39 \cdot 9\end{array}$ & $\begin{array}{l}33 \cdot 7 \\
34 \cdot 3 \\
32 \cdot 7 \\
31 \cdot 4\end{array}$ & $\begin{array}{l}\text { E } \\
\text { - }\end{array}$ & $\begin{array}{c}- \\
-\end{array}$ \\
\hline
\end{tabular}

$H Q$, hind quarter exposed to wind source ; $R$, i.r. radiation.

* Calculated as $0.09 \times W^{\natural}$, where $W=$ body-weight in $\mathrm{kg}$ (Mitchell, r927).

$+\frac{\text { Temperature gradient }\left({ }^{\circ} \mathrm{C}\right)}{\text { Heat flow (kcal) per } \mathrm{m}^{2} \text { surface per } 24 \mathrm{~h}} \times 10^{-3}$.

i.r. radiation 50-60 min after exposure. Measurements of $\mathrm{O}_{2}$ consumption and temperature made after the sheep had been exposed for at least $45 \mathrm{~min}$ to the environment and then continued for $\mathrm{I} h$ thus provide reliable estimates of the metabolic effects of the environment virtually uncomplicated by short-term adaptations.

Effect of wind on metabolism. Table 6 summarizes the results of sixty-six experiments made with sheep $C s$, forty-six with sheep $Y l$, eight with sheep $Z k$ and eight with sheep $C t$ in which air velocity was varied. The sheep had a side presented to the wind in all instances except those noted. The table also includes the results of experiments with sheep $C s$ and $Y l$ in which i.r. radiation was studied. Heat production has been expressed on a $24 \mathrm{~h}$ basis though the measurements were made for periods of about $\mathrm{I}-\mathrm{I} \frac{1}{2} \mathrm{~h}$.

Heat production in wind. Fig. 4 shows the effect of wind velocity on the heat production of sheep $C s$ and $Y l$ when air temperature was $5^{\circ}$ and $-3^{\circ}$. Each curve is labelled with the measured depth of the fleece when the measurements were made. Table 3 showed that the metabolism of sheep $C s$ in a thermoneutral environment was I $80 \mathrm{I}$ and of sheep $\mathrm{Yl} 1892 \mathrm{kcal} / 24 \mathrm{~h}$. When air temperature was $5^{\circ}$ the metabolism of sheep $C s$ with a fleece of $39-5 \circ \mathrm{mm}$ was unaffected by wind until the velocity exceeded 4.2 miles/h. The sheep was clearly at or above its critical temperature at wind speeds 
lower than $4.2 \mathrm{miles} / \mathrm{h}$. When the fleece was $19 \mathrm{~mm}$, metabolism was elevated even when there was no wind. At $5^{\circ}$ sheep $Y l$ was never in an environment that did not elicit a metabolic demand on heat production. When environmental temperature was $-3^{\circ}$, sheep $C s$ was probably slightly above its critical temperature in still air when the fleece was $50 \mathrm{~mm}$. All the remaining experiments with both sheep were certainly in conditions that elicited a metabolic response.

No observations were made with sheep $Y l$ at a temperature of $-3^{\circ}$ at a wind speed higher than $4.2 \mathrm{miles} / \mathrm{h}$ when the fleece was $6 \mathrm{~mm}$. The sheep was then producing $627 \mathrm{I} \mathrm{kal} / \mathrm{h}$, that is 3.3 times as much as when given the same amount of food in a thermoneutral environment, and 5.4 times as much as the $1159 \mathrm{kcal} / 24 \mathrm{~h}$ produced when it was starved in a thermoneutral environment (Blaxter, 1962). This was probably not the maximal metabolism of which the sheep was capable for, as shown in Table 6, rectal temperature was maintained in these conditions. It was, however, thought that the obvious strain on the animal at a wind speed of $4.2 \mathrm{miles} / \mathrm{h}$ was so great that it was likely that it would not survive exposure to a wind of $9.6 \mathrm{miles} / \mathrm{h}$. It is of some interest that the measured heat production of $627 \mathrm{I} \mathrm{kcal} / 24 \mathrm{~h}$ of this sheep was only about $1000 \mathrm{kcal} / 24 \mathrm{~h}$ less than that of a fasting steer weighing about $400 \mathrm{~kg}$ kept in a thermoneutral environment (Blaxter \& Wainman, 196r).

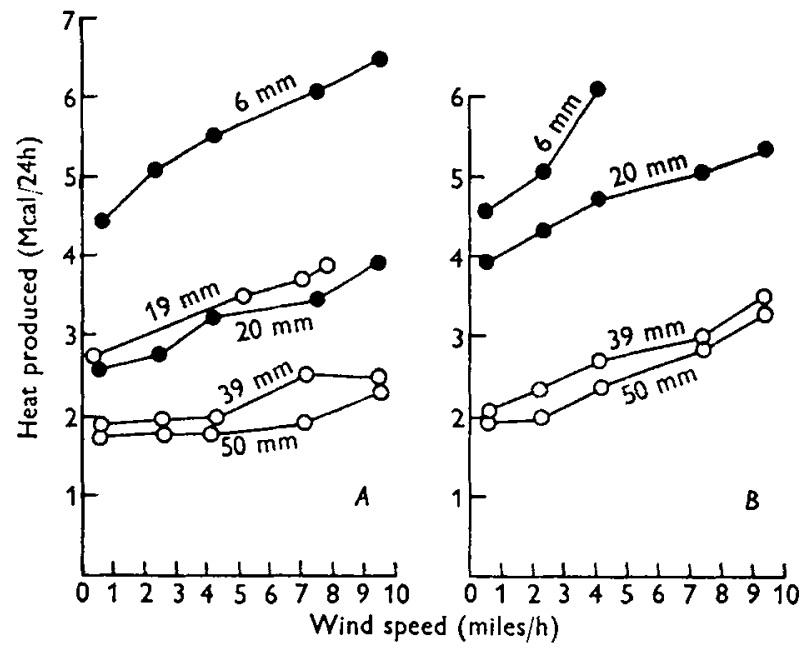

Fig. 4. Effect of wind speed on the heat production of sheep Cs $(\circ-0)$ and $Y l(\bullet-\bullet)$ $A$, air temperature of $5^{\circ} ; B$, air temperature of $-3^{\circ}$. The curves are labelled with the fleece lengths of the sheep.

Rectal temperature in wind. Table 6 shows that when wind speed increased rectal temperature usually rose and that rectal temperature tended to be higher when the sheep was exposed to very low $\left(-3^{\circ}\right)$ air temperatures than when exposed to higher temperatures $\left(+5^{\circ}\right)$. Fig. 5 summarizes these findings and shows the effect of wind velocity on the mean rectal temperatures of sheep $Y l$ and $C s$ at $5^{\circ}$ and $-3^{\circ}$. An increase in the rectal temperature of sheep exposed to cold has been noted by Alexander (196r). 
Insulation of the tissues in wind. The insulation of the tissues was calculated in each experiment in which there was evidence from temperature measurements that the limbs were vasoconstricted. Insulation of the tissues $\left(I_{T}\right)$ is defined by the equation

$$
I_{T}=\frac{T_{R}-T_{S}}{H / A},
$$

where $T_{R}$ is rectal temperature, $T_{B}$ the mean temperature of the skin, as defined on p. 8, and $H / A$ total heat loss/unit area. Table 7 summarizes the results obtained in thirty-nine experiments with sheep $C s$ and $Y l$ in which speed was varied at two environmental temperatures.

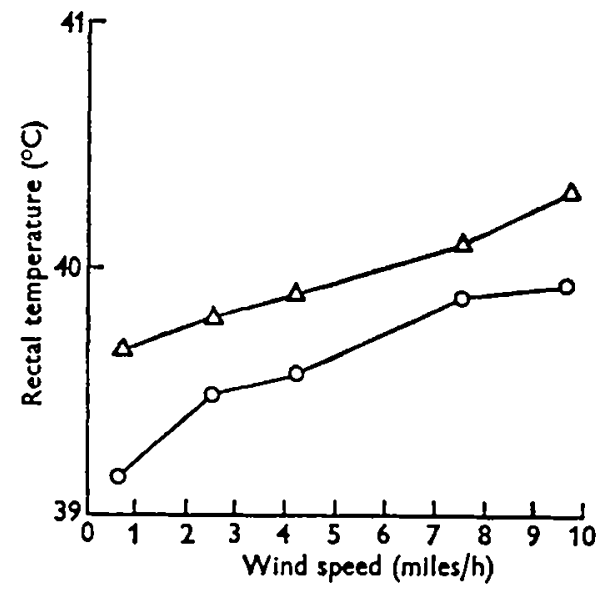

Fig. 5. Effect of wind speed on the mean rectal temperature of two sheep at air temperatures of $-3^{\circ}(\Delta-\Delta)$ and $+5^{\circ}(\circ-0)$.

Table 7. Tissue insulation $\left(I_{r}\right)$ of sheep $C s$ and sheep $Y l$ at different wind speeds and air temperatures

\begin{tabular}{|c|c|c|c|c|c|c|c|}
\hline \multirow[b]{2}{*}{ Sheep } & \multirow{2}{*}{$\begin{array}{l}\text { Fleece } \\
\text { thickness } \\
(\mathrm{mm})\end{array}$} & \multirow{2}{*}{$\begin{array}{c}\text { Air } \\
\text { temperature } \\
\left({ }^{\circ} \mathrm{C}\right)\end{array}$} & \multicolumn{5}{|c|}{$\begin{array}{l}I_{T} \text { (units)* at wind speeds } \\
(\mathrm{miles} / \mathrm{h}) \text { of }\end{array}$} \\
\hline & & & 0.6 & 2.5 & $4 \cdot x$ & 7.5 & $9 \cdot 6$ \\
\hline Cs & $\begin{array}{l}39 \\
50 \\
39 \\
50\end{array}$ & $\begin{array}{l}+5.0 \\
+5.0 \\
-3.0 \\
-3.0\end{array}$ & $\begin{array}{l}5 \cdot 1 \\
5 \cdot 7 \\
7 \cdot 6 \\
6 \cdot 5\end{array}$ & $\begin{array}{l}4 \cdot 6 \\
6 \cdot 7 \\
8 \cdot 1 \\
7 \cdot 0\end{array}$ & $\begin{array}{l}6 \cdot 1 \\
7 \cdot 6 \\
7 \cdot 6 \\
6.6\end{array}$ & $\begin{array}{l}5 \cdot 2 \\
7.6 \\
7 \cdot 9 \\
5.8\end{array}$ & $\begin{array}{l}6.9 \\
6.5 \\
5.6 \\
8.5\end{array}$ \\
\hline$Y l$ & $\begin{array}{l}6 \\
20 \\
20 \\
10\end{array}$ & $\begin{array}{l}+5.0 \\
+5.0 \\
-3.0 \\
-3.0\end{array}$ & $\begin{array}{l}3 \cdot 0 \\
4 \cdot 1 \\
3 \cdot 4 \\
3 \cdot 8\end{array}$ & $\begin{array}{l}3 \cdot 0 \\
4 \cdot 3 \\
3 \cdot 3 \\
3 \cdot 6\end{array}$ & $\begin{array}{l}2 \cdot 9 \\
4 \cdot 1 \\
3 \cdot 3 \\
3 \cdot 4\end{array}$ & $\begin{array}{l}3.3 \\
4.2 \\
3.5 \\
-\end{array}$ & $\begin{array}{l}2 \cdot 7 \\
4 \cdot 0 \\
3 \cdot 7 \\
3 \cdot 9\end{array}$ \\
\hline
\end{tabular}

The results in Table 7 show that fleece length had no effect on the tissue insulation of either sheep in those experiments conducted in environments which elicited a metabolic response to cold. This conclusion is supported by results obtained with these sheep in the remaining experiments. Table 7 shows also that wind speed had no effect on tissue insulation except in sheep $C s$ when wind speed was low and air 
temperature was $+5^{\circ}$. No metabolic response was obtained in this experiment and therefore values were low, for the animal's skin was not vasoconstricted.

There was obviously a marked difference between the insulations of the tissues of the two sheep. The mean values for all determinations with these sheep and for sheep previously studied in this laboratory are given in Table 8 . These results show that the tissue insulation $\left(I_{T}\right)$ of the three Down cross sheep was $3.3-3.9$, that of the three Scottish Blackface sheep 5.4-5.9 and of the two Cheviot sheep 6. I-8.7 $7^{\circ} \mathrm{C} \times 10^{-3} \times \mathrm{kcal}^{-1}$ $\times \mathrm{m}^{2} \times 24 \mathrm{~h}$. The table shows that measurements made on the same individual at different times by different techniques gave similar values, and although the number of sheep was small the results suggest real breed differences in tissue insulation. In this regard Ryder (1955) has shown that the Cheviot sheep has hardly any mid-dermal vessels, the Down breeds on the other hand have a moderately developed mid-dermal plexus of vessels. He made no studies with Scottish Blackface sheep.

Table 8. Tissue insulation $\left(I_{T}\right)$ of sheep in environments in which the temperature was lower than the critical temperature

\begin{tabular}{|c|c|c|c|c|}
\hline Animal & Breed & $\begin{array}{l}\text { No. of } \\
\text { deter- } \\
\text { minations }\end{array}$ & $\begin{array}{c}\text { Tissue } \\
\text { insulation } \\
\text { (units)* }\end{array}$ & Reference \\
\hline Cs & Cheviot & 36 & 6.29 & $\begin{array}{l}\text { This work, Douglas bag } \\
\text { experiments }\end{array}$ \\
\hline Cs & Cheviot & $\mathbf{I}$ & $6 \cdot 13$ & This work, chamber experiment \\
\hline Cs & Cheviot & 3 & $6 \cdot 26$ & I959 chamber experiments $\dagger$ \\
\hline$y_{n}$ & Cheviot & 4 & $8 \cdot 72$ & I 959 chamber experiments $\dagger$ \\
\hline$Z d$ & Blackface & 2 & $5 \cdot 80$ & $\begin{array}{l}\text { This work, Douglas bag } \\
\text { experiments }\end{array}$ \\
\hline$Z d$ & Blackface & 4 & $5 \cdot 35$ & 1959 chamber experiments $\dagger$ \\
\hline$D g$ & Blackface & 3 & 5.90 & 1959 chamber experiments $\dagger$ \\
\hline$C t$ & Blackface & 3 & $5 \cdot 87$ & $\begin{array}{l}\text { This work, Douglas bag } \\
\text { experiments }\end{array}$ \\
\hline$Y l$ & Down cross & 22 & $3^{\cdot 62}$ & $\begin{array}{l}\text { This work, Douglas bag } \\
\text { experiments }\end{array}$ \\
\hline 3 & Down cross & I I & 3.40 & I 956 chamber experiments $\downarrow$ \\
\hline 23 & Down cross & 12 & $3 \cdot 33$ & 1956 chamber experiments $\ddagger$ \\
\hline $\mathbf{2 3}$ & Down cross & 2 & $3 \cdot 90$ & $195^{6}$ chamber experiments $\S$ \\
\hline \multicolumn{5}{|c|}{$\begin{array}{l}\text { * See footnote to Table } 6 . \\
\text { † Armstrong et al. (I960). } \\
\text { I Blaxter, Graham, Wainman \& Armstrong (1959). } \\
\text { \& Blaxter, Graham \& Wainman (1959). }\end{array}$} \\
\hline
\end{tabular}

External insulation in wind. The transfer of sensible heat from the skin to the air can be regarded as a transfer of heat through two insulating layers, that of the fleece and that of the interface of air at the fleece surface where heat is radiated and convected to the surroundings. If the sensible heat flow is known and skin and air temperatures are measured, then it is only necessary to measure the temperature of the surface of the fleece to estimate the insulations of the fleece and the air interface separately. The measurement of this surface temperature is not easy, even in still air conditions, for the nature of the surface of the fleece is such that precise siting of thermocouples at the interface involves some approximation. If a wind is blowing on the fleece the situation is even more difficult for it can then be assumed that, though the location of the 
surface that radiates to the surroundings is the same as in still air, the surface that can be regarded as the convective interface is probably deep in the fleece. Indeed it is extremely difficult to know at what point the process of conduction-convection in the fleece ends and that of convection to the air and radiation to the surroundings begins. This same difficulty occurs with wispy hair coats such as the erected coat of cattle, even in still air (Gonzalez-Jimenez \& Blaxter, 1962).

For these reasons the approach we had adopted previously (Blaxter, Graham \& Wainman, 1959) in dealing with these two terms separately in trials in respiration chambers appears untenable except under still air conditions when the assumption that a fleece-air interface can be defined is possibly acceptable. The alternative is to deal with the whole of the insulation from the sheep's skin where the surface temperature is easily measured and the environment. This insulation is called the external insulation $\left(I_{E}\right)$ and can be defined as

$$
I_{E}=I_{A}+I_{F}=\frac{\left(T_{S}-T_{A}\right)}{H_{N} / A} .
$$

The external insulation is the sum of the insulations of the air interface $\left(I_{A}\right)$ and the fleece $\left(I_{F}\right), T_{A}$ is the temperature of the air for particular air velocity and radiation conditions, $T_{S}$ the mean skin temperature as defined on p. 8 and $H_{N} / A$ the sensible heat loss/unit area. Obviously $I_{E}$ will vary with wind speed. If values of $I_{E}$ are obtained for different fleece lengths at a particular constant wind speed, then the value for $I_{E}$ when fleece length is $O$ can be regarded as an estimate of the insulation of the air interface at that particular wind speed.

Table 9. Regression of external insulation $\left(I_{E}\right)$ on fleece length $(F)$ at different wind speeds determined with sheep $Y l$ and sheep $C s$

$\begin{array}{cc}\begin{array}{c}\text { Wind } \\ \text { speed } \\ \text { (miles/h) }\end{array} & \begin{array}{c}\text { No. of } \\ \text { observations }\end{array} \\ 0.6 & 10 \\ 2.5 & 7 \\ 4.2 & 6 \\ 7.5 & 9 \\ 9.6 & 7\end{array}$

$$
\begin{array}{lcc}
\begin{array}{c}
\text { Regression: } \\
I_{E}^{*}=a+b(F)(\mathrm{mm})
\end{array} & \begin{array}{c}
\text { Standard } \\
\text { error of } \\
\text { regression } \\
\text { coefficient }
\end{array} & \begin{array}{c}
\text { Residual } \\
\text { standard } \\
\text { deviation }
\end{array} \\
I_{E}=4.79+0.463 F & \pm 0.054 & \pm 1.55 \\
I_{E}=4.05+0.397 F & \pm 0.078 & \pm 1.71 \\
I_{E}=3.17+0.331 F & \pm 0.042 & \pm 0.90 \\
I_{E}=2.92+0.348 F & \pm 0.050 & \pm 1.58 \\
I_{E}=2 \cdot 16+0.275 F & \pm 0.078 & \pm 1.21 \\
* \text { See footnote to Table } 6 . &
\end{array}
$$$$
\text { error of Residual }
$$

Table 9 summarizes the results of regression analysis of $I_{E}$ on fleece length at five wind speeds, and individual results for three of these speeds are shown in Fig. 6. The results were obtained with sheep $C s$ and sheep $Y l$ in the climatic room, that is in a room in which wall temperatures were the same as air temperatures and the i.r. emissivity of the walls was 0.98 . In the statistical analysis the within-sheep sums of squares and products were pooled after removal of differences due to individuality of sheep. The results show that at a wind speed of 0.6 miles $/ \mathrm{h}$ insulation increased at the rate of 0.46 units/mm increase in fleece length, whereas when wind speed was $9^{\circ} 6 \mathrm{miles} / \mathrm{h}$, the insulation increased by only 0.27 units $/ \mathrm{mm}$ fleece length. This means that the wind must have penetrated the fleece, and that the destruction of insulation 
on wind speed increasing from 0.6 to 9.6 miles $/ \mathrm{h}$ was $(1-0.27 / 0.46) \times 100=42 \%$. There was no indication that the relationship between external insulation and fleece length was other than linear over the range of fleece lengths studied.

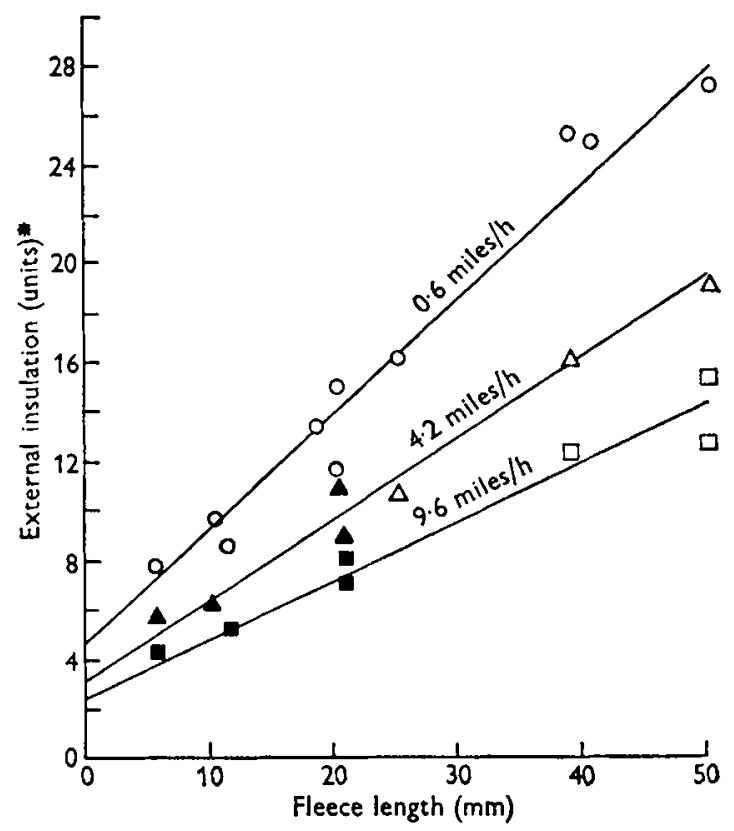

Fig. 6. Effect of flcece length on the external insulation of sheep $C s$ (open symbols) and sheep $Y l$ (black symbols) at three wind speeds. The lines are the pooled within-animal regressions given in Table 9. $\circ, \bullet$, wind speed $0.6 \mathrm{miles} / \mathrm{h} ; \Delta, \Delta$, wind speed $4.2 \mathrm{miles} / \mathrm{h}$; $\mathrm{Q} \cdot$, wind speed $9 \cdot 6 \mathrm{miles} / \mathrm{h}$.

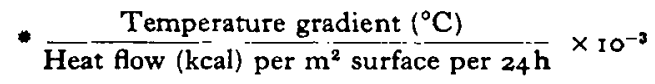

Effect of body position on external insulation in wind. Table ro summarizes results of the five comparisons made between the external insulations of sheep when winds impinged on their sides and on their hind quarters. These experiments include the two shown in Table 6 and the three shown in Fig. I.

Table 10. External insulation $\left(I_{E}\right)$ of sheep in winds that impinged on their sides or on their hind quarters

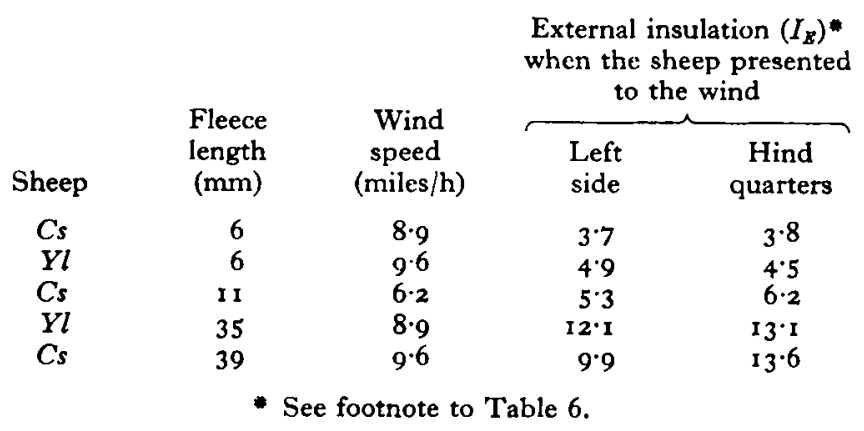


Table 10 shows that when the fleece was very short the external insulation of the sheep was much the same whether the hind quarters or the side were presented to wind. When the fleece was longer, hind-quarter presentation resulted in a higher external insulation. The former results suggest that the siting of the thermocouples on the skin and the averaging of the results from them after weighting the trunk values by 0.9 and the extremity values by $0 . \mathrm{I}$ did in fact provide a good measure of the mean surface temperature, despite the very large gradients of temperature between leeward and windward sides already commented on in the discussion of Tables 4 and 5 . The greater external insulation for hind-quarter presentation than for side presentation when the fleece was long suggests that less destruction of fleece insulation occurred in the former position. The profile presented to a wind is clearly less for hind-quarter than for side presentation which suggests a causal relationship. This aspect has not been investigated further.

Modifying effects of radiation on heat loss in wind. The results of the series of experiments with sheep $Y l$ and sheep $C s$ in which the effect of i.r. radiation on $\mathrm{O}_{2}$ consumption was studied at wind speeds of 0.6 and of 9.6 miles/h are given in Table 6 . With sheep $Y l$ which had $12 \mathrm{~mm}$ fleece, a wind of $9.6 \mathrm{miles} / \mathrm{h}$ compared with one of 0.6 miles $/ \mathrm{h}$ increased heat production by $1570 \mathrm{kcal} / 24 \mathrm{~h}$ in the absence of radiation and by only 664 kcal with radiation. A slight increase occurred in tissue insulation when wind speed was increased irrespective of the radiation. External insulation was markedly increased by radiation. With sheep $C s$, which had a $4 \mathrm{I} \mathrm{mm}$ fleece, the wind of $9.6 \mathrm{miles} / \mathrm{h}$ increased heat production by $386 \mathrm{kcal}$ in the absence of radiation and by $5 \circ \mathrm{kcal}$ with radiation. Tissue insulation fell markedly when radiation was given and wind speed was $0.6 \mathrm{miles} / \mathrm{h}$, and the values with this sheep suggest that it was in fact partially vasodilated throughout the series. External insulation increased when radiation was given.

The results show that variations in the i.r. radiation intensity modified appreciably the animals' reactions to wind. The precise amount of radiant heat that impinged on the animals in these experiments was impossible to assess. Fleece surface temperatures rose considerably, and, though it is unlikely that the conditions imposed in the experiment could arise naturally from variation in i.r. radiation, they may well reflect what happens out of doors when solar radiation is absorbed and liberated as heat at the fleece surface.

\section{DISCUSSION}

Most of the experiments were made with sheep that had fleece depths of $50 \mathrm{~mm}$ or less. When sheep are shorn with hand clippers the fleece depth left is about ro $\mathrm{mm}$, and with efficient machine shearing about $5 \mathrm{~mm}$ remains. The maximal depth of fleece in sheep with fully grown fleeces in early summer is $100-130 \mathrm{~mm}$. The results of these experiments are thus most applicable to sheep during the early months of winter. They can be used to compute expected food requirements under different conditions of air temperature and air velocity, on the assumption that the fleece is dry, that there is no rain, that the incoming i.r. radiation differs little from that expected from a black body at air temperature and that there is no solar radiation. The results should certainly be applicable to dry nights on which there is low cloud. 
From our unpublished studies of the weather statistics of the Eskdalemuir Observatory in Dumfriesshire for the years 1939-49, winds with a mean speed of less than $5 \mathrm{~m} / \mathrm{sec}(\mathrm{I} \cdot 2 \mathrm{miles} / \mathrm{h}$ ) occurred on 237 days out of every 365 and winds with speed greater than II.2 miles/h on the remaining 128 . For the year as a whole the most common (modal) wind speed when air temperature is $-10^{\circ}$ is less than $\mathrm{I}$ mile $/ \mathrm{h}$, at $-5^{\circ}$ it is $2.2 \mathrm{miles} / \mathrm{h}$, at $0^{\circ} 5.6 \mathrm{miles} / \mathrm{h}$, at $5^{\circ} 7.8 \mathrm{miles} / \mathrm{h}$ and at $10^{\circ} 6.7 \mathrm{miles} / \mathrm{h}$. Very cold weather is thus usually still. These sets of combinations can be used to work out approximate food requirements of sheep in the west of Scotland.

The total resistance to cooling of an animal is the sum of the tissue insulation when the skin is vasoconstricted and the external insulation. Tissue insulation, however, must be weighted since it refers to a total heat flow, whereas external insulation refers to a sensible heat flow. As an approximation for all environmental temperatures below the critical temperature, the weighting term can be taken as $H /(H-300 A)$ and the total heat lost by a sheep in $\mathrm{kcal} / 24 \mathrm{~h}$ is thus:

$$
\begin{aligned}
H & =\left\{\left(\frac{T_{R}-T_{A}}{\left[I_{T} H /(H-300 A)\right]+I_{E}}\right)+300\right\} A \\
& =\left\{\frac{\left(T_{R}-T_{A}\right)+300 I_{E}}{I_{T}+I_{E}}\right\} A,
\end{aligned}
$$

where $A$ is surface area in $\mathrm{m}^{2},\left(T_{R}-T_{A}\right)$ is the temperature gradient between the rectum and the air, $I_{T}$ the tissue insulation and $I_{E}$ the external insulation. The external insulation involves specification of fleece length and wind velocity. The constant, 300 , is the minimal loss of water vapour in the cold ( $\left.\mathrm{kcal} / \mathrm{m}^{2} 24 \mathrm{~h}\right)$.

Interpolations in Table 9 enable estimates to be made of the external insulation of sheep with different fleece lengths for the modal wind speeds listed above, and Table I I summarizes the heat losses of a Blackface sheep computed for these specified environments. In computing the results, no allowance has been made for the change in rectal temperature of the sheep that occurred on exposure to cold.

Table I I shows that, over a wide range of environmental temperature at Eskdalemuir, heat losses of sheep in the absence of rain and sun are likely to be fairly constant because the wind speed falls when air temperature is low. The food requirement of these sheep in terms of the metabolizable energy required to maintain weight is the same as the minimal heat production given in the last two columns provided this latter figure is above the maintenance requirement measured in a thermoneutral environment. For a I-2 year old Blackface sheep weighing $50 \mathrm{~kg}$ and taking some exercise, maintenance needs of metabolizable energy are about $\mathrm{I} 900 \mathrm{kcal} / 24 \mathrm{~h}$. Thus even when the fleece is $50 \mathrm{~mm}$ long, the most common wind and air temperature combinations encountered at Eskdalemuir are such that at all air temperatures below $10^{\circ}$ the sheep's requirement of energy for maintenance of weight is greater than that determined calorimetrically. An increase of about ${ }_{5} \%$ in requirement occurs in these most common weather conditions. In severe conditions the increase is much greater. At Eskdalemuir when air temperatures average $-5^{\circ}, 2$ days occur every Io years on which mean air speed is ro miles/h. Total resistance to cooling of a sheep with $50 \mathrm{~mm}$ wool is then about $2 \mathrm{I} \cdot 8$ units and heat production $285 \mathrm{I} \mathrm{kcal} / 24 \mathrm{~h}$, that is maintenance 
needs are increased by $50 \%$. The effects of a mean wind speed of 32 miles/h at a mean air temperature of $2^{\circ}$, conditions which occurred once during the ro-year period of observation, must have occasioned an even greater metabolic demand, but no information about wind speeds of this magnitude is available.

Table I I. Estimated minimal heat production in different environments of a Blackface sheep weighing $50 \mathrm{~kg}$ at $I_{T}=5.7$ units and $T_{R}=390^{\circ}$

\begin{tabular}{|c|c|}
\hline \multicolumn{2}{|c|}{$\begin{array}{l}\text { Charactcristics of } \\
\text { the environment }\end{array}$} \\
\hline $\begin{array}{c}\text { Air } \\
\text { tempera- } \\
\text { ture } \\
\left({ }^{\circ} \mathrm{C}\right)\end{array}$ & $\begin{array}{l}\text { Modal } \\
\text { wind } \\
\text { speed } \\
\text { (miles/h }\end{array}$ \\
\hline-10 & 0.5 \\
\hline & \\
\hline & 5.6 \\
\hline+5 & 7.8 \\
\hline + 10 & 6.7 \\
\hline
\end{tabular}

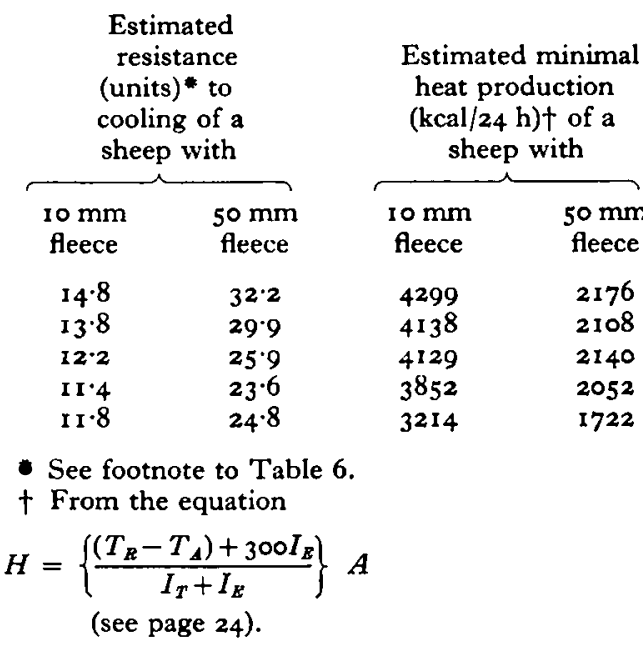

Table 8 showed some evidence that the tissue insulation of Down cross sheep was. lower than that of hill breeds. The effect of this difference in tissue insulation on heat production in adverse climates is not as great as might be casually inferred from Table 8 , since tissue insulation is usually a small component of the total resistance to cooling. The fleece and air insulations are numerically greater except when the fleece is very short and wind speed high. If the tissue insulation of a Cheviot sheep is taken as $\mathbf{6 \cdot 2}$ and that of a Down cross is taken as 3.5 units, that is the Down cross has $56 \%$ of the tissue insulation of a Cheviot, then at an air temperature of $5^{\circ}$ and a wind speed of 4.2 miles/h, the maintenance requirements of a Down cross with a fleece length of Io $\mathrm{mm}$ can be calculated to be $27 \%$ greater than that of a Cheviot of the same weight and fleece length. When the fleece is $50 \mathrm{~mm}$, however, the maintenance requirement of the Down cross is only I $1 \%$ greater. Even though large differences in tissue insulation have small effects on total heat losses in cold environments, the fact that they exist and that tissue insulations are higher in mountain breeds suggests that some progress might be made in breeding for resistance to cold.

\section{SUMMARY}

I. Experiments with four tracheostomized wether sheep were made to determine the effects of changes in air velocity, i.r. radiation intensity and air temperature on their heat emission and temperature regulation. The accuracy of measurements of oxygen consumption and methods of converting such measurements into estimates of heat production are given. 
2. Responses of the $\mathrm{O}_{2}$ consumption of sheep to changes in air velocity were virtually complete $50 \mathrm{~min}$ after exposure, responses to changes in air temperature $30 \mathrm{~min}$ after exposure and responses to changes in i.r. radiation 50-60 min after exposure.

3. Responses of skin temperature of the trunk to changes in air velocity were very rapid. They were also rapid for changes in air temperature, but with changes of i.r. radiation intensity, although initially the responses were rapid, subsequently they were slow. In all experiments the response of the skin temperature of the foot to changes in climate was much slower than that of the trunk, being completed in periods of time similar to those noted for $\mathrm{O}_{2}$ consumption.

4. Heat production was increased by wind, a value 3.3 times that noted in the thermoneutral zone being observed with a sheep with a short fleece kept at $-3^{\circ}$ in a wind of $4 \cdot 2$ miles/h. Rectal temperature increased with wind velocity.

5. Tissue insulation of the sheep once vasoconstriction had occurred was unaffected by wind velocity or by environmental temperature. Evidence is presented that the tissue insulation of Blackface and Cheviot sheep is greater than that of Down cross sheep.

6. External insulation, defined as the joint insulation of the air interface and the coat, increased linearly with fleece length over the range 5-50 $\mathrm{mm}$. External insulation fell with increasing wind velocity, the fall being numerically greater when the fleece was long than when it was short. Partial destruction of coat insulation by wind was detectable for the whole range of wind speeds studied $(0 \cdot 6-9 \cdot 6 \mathrm{miles} / \mathrm{h})$ and was $42 \%$ at $9.6 \mathrm{miles} / \mathrm{h}$.

7. Heat loss was reduced in a given air velocity when the sheep's hind quarters rather than its side were presented to the wind but only when the fleece was long. Wind resulted in the devclopment of very large windward-leeward gradients of skin temperature.

8. The increase in heat production of the sheep on subjecting it to wind was greater when incoming radiation was small than when it was increased by i.r. heaters.

9. It is calculated from weather records that, even when effects of rain and of decreased incoming i.r. radiation on heat emission are ignored, sheep kept out of doors in Scotland have maintenance energy requirements much greater than those determined in the thermoneutral conditions of the respiration chamber.

\section{REFFRENCES}

Alexander, G. (1961). Aust. F. agric. Res. 12, I 152.

Armstrong, D. G., Blaxter, K. L., Clapperton, J. L., Graham, N. McC. \& Wainman, F. W. (I960). †. agric. Sci. 55, 395 .

Bedford, T. \& Warner, C. G. (1933). F. Hyg., Camb., 33, 330.

Blaxter, K. L. (1962). Brit. F. Nutr. 16, 615.

Blaxter, K. L., Graham, N. McC. \& Wainman, F. W. (1959). J. agric. Sci. 52, 41.

Blaxter, K. L., Graham, N. McC., Wainman, F. W. \& Armstrong, D. G. (1959). F. agric. Sci. 52, 25.

Blaxter, K. L. \& Joyce, J. P. (1963). Brit. F. Nutr. 17, 523.

Blaxter, K. L \& Wainman, F. W. (1961). F. agric. Sci. 56, 81.

Findlay, J. D., McI ean, J. A. \& Bennet, R. D. (r959). Heat. Vent. Engr. 33, 95.

Golding, E. W. (1961). In Natural Resources in Scotland, p. 468. Edinburgh: The Scottish Council (Development and Industry). 
Gonzalez-Jimenez, E. \& Blaxter, K. L. (1962). Brit. F. Nutr. 16, 199.

Graham, N. McC., Wainman, F. W., Blaxter, K. L. \& Armstrong, D. G. (1959). J. agric. Sci. 52, I3. Mitchell, H. H. (1927). Rep. Ill. agric. Exp. Sta., p. 55.

Robinson, J. F. (1953). Survey of Blackface Sheep with Special Reference to their Hardiness. Edinburgh: H.M. Stat ionery Office.

Ryder, M. I. (1955). Proc. Inst. Wool. Textile Res. Conf. Australia, Sect. F, p. 63.

Wainman, F. W. \& Blaxter, K. L. (1958). EAAP Publ. no. 8, p. 85. 